\title{
Maximizing our resources in resource management
}

\section{R. BAKEWELL}

C. D. Schultz \& Company Limited Vancouver, British Columbio
L'auteur suggère que les polémiques qui se forment au sujet des développement des richesses naturelles peuvent être diminuées si on y apporte les efforts voulus au tout premier stage de la planification. Cependant, ces efforts requièrent plus que de simples considérations techniques de sorte qu'ils peuvent nuire à mise en oeuvre optimale.

Pour assurer le progrès en ce domaine, il faut principalement:

a) des inventaires adéquats de toutes les richesses présentes en une region définie; une préparation $d u$ plan de développement des richesses intégrées qui soit la plus bénéfique possible pour les intérêts du public.

b) une éducation auprès du public dès les premiers stages de ce développement afin d'enrayer toute opposition à la mise en oeuvre de ces richesses.

c) à l'occasion donnée au public afin que ce dernier puisse faire valoir ses griefs lors de l'élaboration du plan en question.

d) une centralisation des autorités dans un but de coopération accrue des divers responsables vis-à-vis des richesses mises en oeuvre en cause.

e) une plus grande participation des gouvernements due aux couts élevés requis dans les phases préopérationnelles.

Une question importante subsiste cependant: le public est-il préparé à $y$ mettre du sien dans ce genre de développement à long terme des richesses naturelles?
From the paper presented to the 62 nd Annual Meeting of the Canadian Institute of Forestry, Winnipeg, October 1970.
Society has accepted that planned multi-purpose development of resources is necessary. Also society has accepted that resource management is necessary. Many people understand that satellites can obtain resource inventory data, radio active elements can trace pollution sources, and computers can process technical data. Enabling legislation is in force to abolish non-conforming practices which do not follow accepted standards of sanitation, protection, use, and pollution.

Why then, with all these basic premises accepted as public policy and with all the scientific aids at our disposal, are resource development controversies raging throughout Canada and some other parts of the world?

In concept, development is any improvement or change to the virgin state of the resource. Accordingly, development can be considered from the building of a trail in a park to the implementation of a pulp mill wood supply, from the removal of beaver dams on a river canoe trail to the construction of a hydro-electric dam, or from the designation of a wilderness area to the creation of a day-use park. The expanding national and world demands for water, energy, food, forest products, minerals, and recreation dictate that Canada must continue to develop natural resources.

- If controversies are to rage each time an announcement is made of a new development, or wilderness reserve, or conservation measure, how can the people be assured that the developments are sound and planned in the long-term public interest?

- What technical and regulatory processes must be followed to compromise the demands of promoters, government agencies, investors, conservationists, and the public?

- What techniques are needed in the planning processes to develop decisions which avert controversies and permit optimum development?

The foregoing questions indicate that the public is inevitably going to play a continuing part in the future decision-making processes in resource development. Accordingly, an examination of the implications of this participation should indicate some factors that will have to be hereafter considered in resource development planning.

\section{Historic planning of resource developments}

Until a few years ago, the planning and implementation of resource developments were rather simple processes. For instance, the promoters of a pulp mill development located an industry adjacent to a source of timber, power, and water. Essentially the decisions resolved around the economic development of the physically available timber. Minor considerations were given to water and air pollution, wildlife, and sociological aspects of the communities for the workers. Legislation and regulations were simple and permissive. Often generous allocations of timber and resource rights, economic subsidies, and government social contributions were available as incentives for the promoters and developers. The developer had to pay little heed to the requirements and demands of associated natural resources.

Similar lack of public concern was expressed in single purpose development of water, agriculture, mineral and petroleum resources. Examples of single purpose developments exist from coast to coast in 


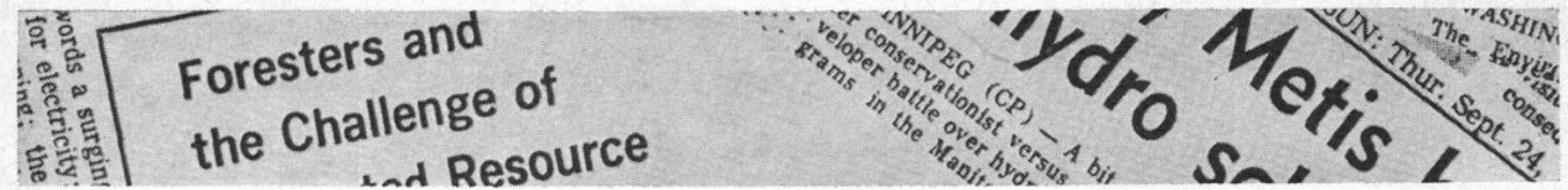

the form of pulp mills and industrial plants discharging harmful effluents into waterways, hydro dams on fish rivers, uncleared reservoirs, encroaching agriculture on wildlife breeding marshes, and massive appropriations of prime agricultural land for urban sub-divisions and industrial projects.

In summary, decision-making for planning processes of single purpose developments was largely influenced by economic considerations. Political requirements were negligible because the public had minimal participation in the project.

Today, similar single purpose use is encouraged in other developing countries. Large concessions, tax holidays, permissive regulation and direct financial assistance are available to investors willing to open up the natural resources in parts of southeast Asia, Africa, and Latin America.

\section{Reflections of historic development}

Economic reflections. The era of single purpose development of resources has proven very beneficial to Canada. Canada has some of the most highly developed and valuable resource industries on a per capita basis of any country in the world.

The forest industries production is valued at nearly 4 billion dollars per year, or about $\$ 200$ for every man, woman, and child. Annual incomes of other resource industries are: agriculture and mineral, over 4 billion dollars each; electric energy from hydro-generation, nearly 1 billion dollars; and tourist industry, nearly 4 billion dollars. In addition, Canada has park reserves of over 113,000 square miles.

A network of highways, railroads, and utility systems links cities from the Atlantic to the Pacific, many parts of which depend on freight or traffic in raw or manufactured form from the resource industries.

Pioneer resource industries have created modern communities with demands or requirements often initially beyond the limits of public services and transportation. The social requirements for housing, schools, hospitals, and recreation facilities in remote areas have put immense strains on both government and private investors. The cost of community and social requirements of some pulp mill developments in the north now exceeds $10 \%$ of the cost of the basic production units. Furthermore, operating subsidies are often needed to encourage private investment in hotel, supermarket, and entertainment facilities because of limited business in early stages of operation.

To encourage development, governments provide incentives for community development. The costs of such subsidies are paid for ultimately by the public through higher taxation. However, the availability of loans, mortgages, or grants from Central Housing and Mortgage Corporation and other gov- ernment agencies plays a major part in the initial start of some forest, mining, and hydro developments. Furthermore, the concept of "Instant Towns" with full municipal privileges and financing backed by enabling legislation provides incentives for investment in remote regions.

Political reflections. The controversies which arose from the single purpose development planning of resource use have reflected in our political institutions and processes.

A pattern of government has evolved which allows the public to participate in the resource developments. Departments have been incorporated specifically for the planning and management of resources, conservation of resources, promoting industrial development, controlling industrial development, exploration of new resources, curtailing development of resources, controlling pollution, and for controlling incomes and revenues.

A public awareness has evolved which is becoming increasingly resource-oriented. The people are demanding more leisure time and increased opportunities to enjoy or utilize the benefits of our natural resources.

Unwise use of some resources has caused the public to react and demand reparative measures. Frequently, the instruments of protest such as resource institutions, societies, legislatures, and government bodies are only aroused or evoked after the serious damage has been done to a second resource. Often drastic remedial measures are required, and public opinion forces governments to take emergency actions. This form of protest politics and lobbying appears to be more often than not obstructive rather than constructive. Counter measures are applied on a catastrophic repair basis rather than on a considered prevention basis.

The demands for total abolition of pollutant industries, complete clean-up of uncleared reservoirs, and banning of commercial fishing and forest operations in recreation areas are symptoms of overcompensation resulting from public concepts of former exploitation.

People have depended on governments to make wise decisions on resource developments. The controversies indicate that the governments and basically the system of decision-making have failed to meet the people's expectations. Hindsight often shows that the initial decisions were based only on part of the information which should have been considered for optimum planning. Essentially traditional methods of assessing resource developments have not provided for the fact-finding and analysis of all the associated factors which may influence longterm suitability.

The spring floods no longer inundate some 1,000 square miles of delta marshlands in the vicinity of Athabasca Lake because of the Bennett Dam on the 


\section{Banker puts land use tirst}

Peace River. The marshlands are drying up with apparent damages to the ecology of the region. Alberta places full blame on the Bennett Dam. British Columbia counters that a three-year low water period is the cause.

Undoubtedly, both factors have contributed to the drying up of the delta. However, this type of controversy illustrates a problem which could have been averted with integrated resource studies. The possible depletion of the delta resources could have been foreseen. Cooperation between affected parties at early stages of development might have allowed conservation measures which are no longer feasible.

The recent advent of the Ministers' Land-Use Committee in British Columbia is a significant step in government resource planning. This Committee is composed of the Ministers of Lands, Forests and Water Resources; Agriculture; Recreation and Conservation; Mines and Petroleum Resources; and Municipal Affairs. The operation of the Ministers' Committee exposes the single purpose government departments, each of which administer a resources act, to experiences in integrated land-use and resource planning.

Frequently, governments appoint Royal Commissions to receive evidence on conflicting resource uses. Often, these Commissions are used as political expediences to delay making decisions on political or administrative issues. Most Commissions hear evidence on a volunteer basis. As most do not have investigatory powers to undertake original fact-finding, the evidence submitted may not contain the data essential for establishing proper policies or actions. Knowledgeable people are seldom subpoenaed to provide expert evidence.

Promoters are a necessary part of the resource development process. The failure of promoters, both private or government, to inform the public in the early stages of planned or proposed developments has sometimes caused embarrassing and costly delays. Often the public interest in resources appears to have been completely overlooked. Once the momentum of protest politics based on misinformation is underway, tremendous efforts are required to reverse the public opinion. Misinformation and prejudices are not easily overcome despite how simple the facts may be in favour of the proposed development.

The North American Water and Power Alliance, commonly known as NAWAPA, is a scheme for the continental development of water and power resources. The company which developed the concept only linked the publicly announced projects. The company advocates that integrated studies should be undertaken so that long-term benefits might not be lost by deficiencies in projects ready for construction. The company's recommendations are lost in the nationalistic claims of resource own- erships and values.

Behavioural reflections. The older established industries are being plagued by the communities they created for control of smoke and water pollution, use of private roads, and recreational privileges on private lands.

These public demands have initiated a pattern of public behaviour which must be considered in resource development planning. The agricultural, mining, and forest industries pioneer developments in remote regions. The first people in a region depend entirely upon the basic industry. As the population and the communities prosper, greater numbers of people are employed in secondary pursuits and become a growing influence on the social and political welfare of the community. Soon the majority of the people has no direct connection with the basic industry which provides the founding basis of the local economy. Accordingly, unreasonable demands on the pioneer industries for recreational, social, and environmental improvements create little sympathy from the local public as to the economic or the physical implications.

Thus, at a certain point, the demands for alternate resource uses and better environmental conditions become matters of public numbers rather than of public dependencies. Accordingly, the agricultural and forest domains are being used increasingly for urban, social, and recreational purposes. The costs of these additional uses are not always borne in full by the original development. Governments have been forced to assist financially with tax incentives for retaining agricultural status of lands and for installation of pollution control measures. The public appears willing to accept higher taxation for payment of such direct and indirect subsidies as part of the privilege of better living conditions.

An interesting behavioural reflection has developed where some companies are allowing access privileges on private lands and roads. By welcoming the public and encouraging good community relations, costs of vandalism and property protection are no greater than when the policy was to prohibit public use.

\section{Requirements for future developments}

Integrated resource development. Optimum management of resources depends on obtaining good basic data of relative weight during the planning operations. Resource developments must account for environmental and ecological influences which heretofore have been of little concern. Accordingly, factfinding and data analysis processes have to be done by managed teams of specialists with expertise in forestry, fisheries, hydrology, agriculture, mineralogy, economics, sociology, meteorology, wildlife and politics. 


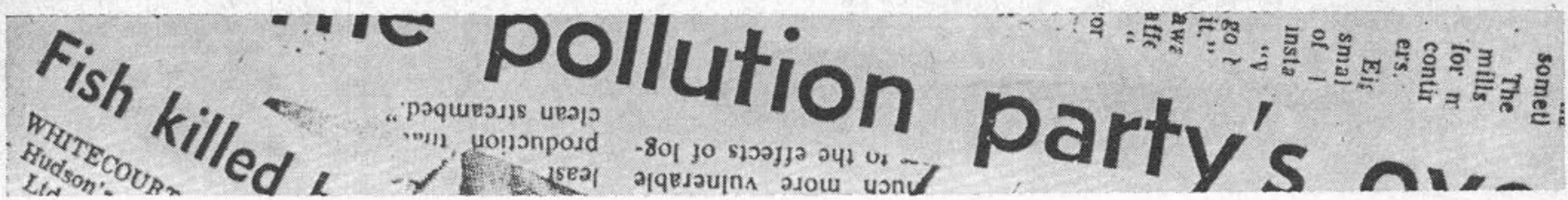

This process of analyzing and weighing data of many disciplines and technologies requires new concepts and objectives in the decision making during the planning operations. Both quantitative and qualitative data must be digested so that solutions are evolved that balance the social, political and aesthetic factors of development with the acceptable physical and economic limitations.

The requirements for analyzing objective and subjective data simultaneously necessitate that money is no longer the basic unit of valuation. Cost-benefit analyses and mathematical models have to incorporate new units of measurement such as "utiles" or weighted subjective values.

Integrated resource developments have to be evalued with constraints for benefits which should develop with good management. Allowances have to be made for the advent of changed public opinion, recreation after opening up of road systems, or creation of reservoirs, and deletions for rights-ofways, wilderness areas, or urban development. Finally, integrated development valuations have to be presented so as to encourage maximum support from the developer, investor, government, and the people.

Education of public. The resource development participants, whether government or industry, or both, must accept responsibilities for educating the public about resource developments. All interested or affected people must be informed of the facts in advance so that they can make decisions based on facts. Favourable public reaction to proposals is an absolute necessity in the early stages of planning. The public must also be educated to accept that long-term planning proposals often require sacrifices which may affect local development.

People have to be educated that multi-resource planning usually embraces larger regions of influence and consequently requires the consideration of the welfare of a larger population. The optimum benefits to the greatest number of people have to be given precedence.

The expropriation of lands and waters for hydro projects, rights-of-way, and parks frequently causes severe hardships for local residents for a short period of time. However, the long-term benefits to many people of the large power and navigation projects developed in the past, such as the St. Lawrence Seaway and the Columbia River Development, have not provided sufficient evidence to date to convince the public that the damming of the Fraser River, or other fish rivers, is in the longterm public interest.

Conversely, the public has accepted decisions for the allocation of forest cutting rights to allow the creation of large integrated sawmill-pulpmill developments at the expense of small local sawmill operators.
Public participation. The public has an ever-increasing desire to participate in resource development. Accordingly, planning of resource developments must provide for a system where:

- Facts are gathered and analyzed by managed teams of experts embracing all the disciplines of the technical, economic, legal, and social aspects of the physical sciences and human resources likely to be affected by the development over a long period.

- Data can be progressively made available to the public and affected parties in early stages of planning.

- The public can voice opinions at open hearings in order that, where possible, all facets of controversial subjects based on facts can be taken into account in the decision-making process.

- The planners and technical experts accept compromises in optimum resource use to satisfy the public opinion despite the technical facts to the contrary.

- The implementation of any resource planning is subject to long delays because of the appeals and legal restrictions.

With informed public participation based on thorough fact-finding, decision-making processes will insure that the results are the best balance between the public's wants and the professional's conclusions. Only with the public support will the funds be made available for implementation. Also, people may be more content to live with decisions in which they had had meaningful participation.

As illustrated by present public concern about pollution and conservation, governments have tremendous public support to impose severe restrictions on industry.

Regulatory authority. In order to efficiently implement effective planning, present forms of government organizations will have to be revised so that all resources departments are coordinated under a common ministry. To avoid major conflicts in some resource uses, the jurisdictions of the federal, provincial, and municipal governments may have to be revised despite historical precedents and constitutional rights.

The integration of government agencies will eventually lead to more uniform legislation and allow more effective planning and controlled development. More centralized authority infers greater regimentation of society, restriction of individual decision, and enforcement of curbs on pioneer developments.

Economic inventives. Effective planning for integrated resource development requires complete inventories of all the affected resources. Accordingly, considerable costs are going to be incurred in the pre-operational phases. These higher than presently acceptable costs will be a definite negative factor in encouraging private investment. Thus, govern- 
ments will be pressured to provide the extra money for planning. Increased taxation is inevitable. Again a question arises as to what degree the public is prepared to support better planning for long-term benefits, especially when funds are urgently needed for schools, hospitals, and welfare.

The suggestions of integrated resource planning, public hearings, and delayed decisions are not conducive to investment of private capital in resource developments.

The underwriter or financer is most concerned with the payout period and the return on his investment. The incalculable pre-operational expenses and possible delays in the investigatory stages will definitely influence the availability of money for resource development. With the increasing emphasis on integrated resources use, and especially with public demands for pollution control, recreation, and social facilities, investors will examine proposals for developments with ever-increasing care. Projects with potential controversies likely to delay construction and operational start-up will be treated with great caution.

Private investment will continue to pay for shortterm planning, but governments will be required to assist with long-term planning. The inevitable result will be greater participation of the government in industrial resource developments. The hydro projects in all provinces, pulp mill developments in Saskatchewan and Manitoba, and mining developments in the north, are already forerunners of the forthcoming trends.

\section{Summary}

The foregoing suggestions indicate that resource development controversies can be minimized with increased efforts in the planning stages. However, these efforts involve far more than technical considerations, and therefore may be slow in optimum implementation. Progress in resource planning and management appears to involve primarily:

- Inventory of all resources in a region and preparation of integrated resource development plans most beneficial to all sectional interests of the public.

- Education of the public in early stages of resources development to offset misinformed opposition.

- Opportunity for the public to voice opinions on controversial subjects as part of the planning process.

- Centralization of authorities to manage associated resources under common regulatory authorities.

- Greater government participation in resource development because of requirements for increased costs in pre-operational phases.

In summary, the people are going to increasingly participate in the development of resources. Accordingly, all planning hereafter must provide means of optimizing all public benefits. This demand will entail a constant evaluation of new concepts to integrate scientific knowledge of resources with human desires. 


\title{
DISTRICT FORESTRY OFFICERS
}

\author{
Lands and Forests Service \\ Department of Indian Affairs and Northern Development \\ Northwest Territories
}

The Department of Indian Affairs and Northern Development is currently initiating an expanded program of renewable resource management in the Northwest Territories involving land use, water and forest resource management, fire control and generally a comprehensive program for the prevention and control of pollution and environmental degradation. To operate this program in the field, three new Land and Forest Districts have been established, with their respective headquarters at Inuvik, Yellowknife and Fort Smith, Northwest Territories and openings now exist for experienced graduate foresters at these locations.

\section{DISTRICT SUPERINTENDENTS}

\section{Forestry Officer $3, \$ 11,515$ to $\$ 13,704$ plus northern allowance}

(Inuvik, Yellowknife and Fort Smith, Northwest Territories)

\section{Duties}

Under the direction of the Superintendent, Lands and Forests Service for the Northwest Territories, the District Superintendent implements, directs and administers resource management programs, including timber management, regulation of surface land use operations and environmental protection, forest fire control, and some water resource management programs, within a designated District; collects data, analyses and recommends action on problems and proposals concerning multiple resource use; supervises the work of Resource Management Officers and other subordinate staff located throughout the District; directs the enforcement of legislation with respect to the utilization, conservation and management of water, forest and land resources; and performs other related duties connected with the Department's responsibilities for renewable resources management.

Because of the vast size and diversity of the far northern territories, certain duties may be emphasized more than others, depending on the District to which a person is assigned.

\section{Qualifications}

Graduation with a Bachelor's Degree in Forestry, with several years' experience either with industry, a government forest service or resource management service involved in problems of forest and land management related to multiple resource use and resource protection. For the Inuvik District in particular, direct experience in environmental protection and a knowledge of operation procedures used in oil and gas exploration and development would be an asset.

\section{STAFF FORESTER}

\section{Forestry Officer $2, \$ 9,603$ to $\$ 11,302$ plus northern allowance}

Applications may also be considered for a position of staff forester to work under the supervision of the Superintendent, in the fields of timber management and forest fire control. This position requires a degree in forestry and general forestry experience. The position will be located at the field headquarters in Yellowknife.

\section{APPLICATIONS AND ENQUIRIES}

This competition will remain open until the positions are filled.

Applicants should forward a detailed résumé to: -

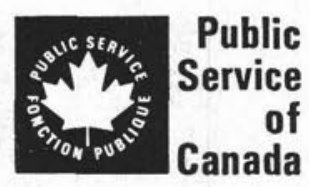

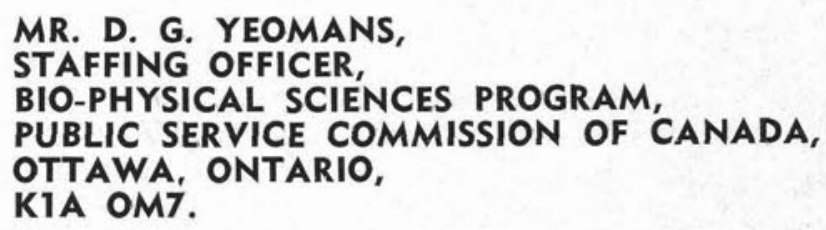

MR. D. G. YEOMANS, STAFFING OFFICER, BIO-PHYSICAL SCIENCES PROGRAM, PUBLIC SERVICE COMMISSION OF CANADA, OTTAWA, ONTARIO, K1A OM7.

Please quote competition number 71-1550 in all correspondence relating to these positions. 